\author{
Jed Lea-Henry \\ Vignan University (India)
}

\title{
The Responsibility to Protect (R2P) and the Problem of Political Will
}

\begin{abstract}
The Responsibility to Protect (R2P) was created in the hope of overcoming the barrier that state sovereignty, as a principle, had become to actions of humanitarian intervention. It was imagined that as mass atrocity crimes were coming to the attention of the international community, that, on the whole, they were willing, able and eager to intervene in order to stop the violence in question. Holding them back was sovereignty as both a legal and normative barrier. This was always a bad explanation for the pervasive lack of humanitarian intervention; accordingly R2P, as a bad solution, has failed almost entirely. The problem is, and always has been, that when faced with mass atrocity crimes, the international community is plagued by a near-permanent lack of political will to action.
\end{abstract}

Keywords: responsibility to protect; $R 2 P$; humanitarian intervention; international crimes; international law

“The international community's actual record of preventing and halting the mass killing of civilians is staggeringly poor"

- Alex Bellamy

\section{Introduction}

Humanitarian intervention, as a principle means of alleviating human suffering resulting from mass atrocity crimes, carries significant moral and legal force; an important tool for the protection of human rights. Conversely, the principle of non-intervention, under the larger banner of state sovereignty, exists as a guarantee of international equality, peace and security, and is supported by a significant moral and legal structure. The perception has been that this dilemma has produced indeterminacy in the practical application of humanitarian intervention; a phenomena that became defined by the controversy and failure surrounding the erratic application of humanitarian intervention in the 1990's and early 2000's. 
Faced with countless examples during this period, and with the theoretical contradiction of 'humanitarianism vs. sovereignty' seeming to cause most of the problems, Secretary General of the United Nations (UN) Kofi Annan, pressed for urgent reform at the supranational level; the need to "forge unity" (ICISS, 2001, p. vii) when confronted by the next inevitable humanitarian crisis. The solution was the Doctrine of the Responsibility to Protect (R2P); a new legal, moral and normative standard for the international community to live by in response to mass atrocity crimes.

However despite some early stage successes, both in institutional and practical terms, R2P never really got going. As a doctrine it died an embryonic death, and remains today largely unimplemented as a policy directive (Bellamy, 2010). The same indeterminacy that plagued humanitarian intervention, has continued to plague R2P. The original explanatory theory behind the indeterminacy (humanitarianism vs. sovereignty) was wrong, and in some ways R2P helped to clarify the real problem. By imposing a new clarification over the competing international values of state sovereignty and humanitarian intervention, R2P shed extra light on what had been the barrier to intervention all along: 'compliance pull'. The old paradox was dead, and the 'ethics verses politics' problem was brought to the fore. The failure of R2P, just as with the sustained failure of humanitarian intervention before it, was reducible to a single issue: an underlying absence of political will.

\section{Humanitarian Intervention}

Although its origins can be predated by almost half a century (Barnett, 2011, p. 5), Humanitarianism holds Jean-Henri Dunant as its patriarch. In 1859, after happening upon the Battle of Solferino, and watching the unfolding day of carnage as Emperor Franz Josef of Austria and Emperor Napoleon III of France fought a single day battle, his horror at the bloodshed and the misery of soldiers dying unaided, long after the fighting was over became the impetus for the formation of the International Committee of the Red Cross (ICRC) and the Geneva Conventions - a codification of what is "honourable and dishonourable" between human beings (Ignatieff, 1999, p. 117-118). It is from this emotional imperative, that "if we can save innocent lives or protect populations, we should do so" (Holt \& Berkman, 2006, p. 29), that the concept of humanitarian intervention gains legitimacy. Humanitarianism is a response, rather than a universalistic claim concerning human nature, based "less on optimism about the human capacity for good than on dread of human capacity for evil, less on a vision of man as maker of his history than of man the wolf toward his own kind" (Ignatieff, 1999, p. 18).

When humanitarian intervention is discussed, it is helpful to narrow the conceptual framework to an idea of: "military interventions... against the wishes of a government, or without meaningful consent, and with humanitarian justifications" (Weiss, 2007, p. 5), or alternatively for Eric Heinze it is: "the transboundary use of military force for the purpose of protecting people whose government is egregiously abusing them, either directly, or by 
aiding and permitting extreme mistreatment" (Heinze, 2009, p. 2). The issue of consent or lack thereof is often a controversial issue itself, that can be irrelevant as was the case in Somalia, void of practical meaning as in Sierra Leone, Haiti and Liberia or ambiguous as was the case of Indonesia's claim to East-Timor (Weiss, 2007,p. 6). The issue of humanitarian intervention is often starkest in circumstances where it is unsolicited and resisted, such as in the former Yugoslavia and Rwanda. More solicited forms of humanitarian intervention are often better categorised under the labels 'humanitarian assistance' or 'humanitarian aid'. As such, terminologically, humanitarian intervention can be misleading, alternative propositions are 'humanitarian war,' 'humanitarian military intervention', or as Kofi Annan proposes "of course military intervention may be undertaken for humanitarian motives... [but]...let's get right away from using the term 'humanitarian' to describe military operation" (Weiss, 2007, p. 11). Humanitarian intervention is war, but war in the context of a world where 1 in 135 of the total global population requires international assistance and/or protection as a result of existing conflicts (Weiss, 2007, p. 73). Gareth Evans explained it well by acknowledging that there is a "mistake of going to war when we should not, but also what can sometimes be the even bigger mistake of not going to war to protect our fellow human beings from catastrophe when we should" (Evans, 2006, p. 722).

As solid as the moral basis for humanitarian intervention may be, the legal case is slightly more complex, and reliant upon the steady evolution of normative guidelines, through their application in practice and by the attempts of various scholars to develop a functional framework. There exists four core claims to the legality of humanitarian intervention, 1 . The plain meaning and language of the UN Charter. 2. Viewing the UN Charter as an "organic document" that should be applicable to and fulfilling of, current developments in human rights law, as has been the case with a large body of legal argument detailing that 'aggression' under the UN Charter, does not encompass 'humanitarian aggression' (Chomsky, 2012, p. 149). 3. By viewing customary law or normative behaviour as the legal basis for state behaviour (Heinze, 2009, p. 58), as established to exist as a legal compliment in the Paquete Habana Case (1900) (Hehir, 2008, p. 23). And, 4. Based on codified human rights standards, as established primarily in the UN Charter 1945, The Universal Declaration of Human Rights 1948, the Covenant on Civil and Political rights 1966, the covenant on Economic, Social and Cultural rights 1966, the Geneva Conventions 1949 and 1977, the Conventions against Torture, Cruel, Inhuman or Degrading Treatment or Punishment 1975 and 1984 and the Genocide Convention 1948 (Weiss, 2007, p. 21). And conceptualised as pluralistically as possible, via the sort of minimalist approached posited by Michael Ignatieff, where human rights should exist as a "tool kit against oppression", relational to negative liberties; that is, freedom from interference - a means to protect our 'agency' (Ignatieff, 2003). Moreover, the "legal standards for the governance of humanitarian intervention is the principle of universal jurisdiction, which permits the national courts of states to prosecute individuals based solely on the nature of an international crime" (Heinze, 2009, p. 85-86). However, the legal grasp of these provisions is fragile and unconvincing, and there is no explicit "humanitarian 
exception" in the Charter concerning the right of intervention (ICISS, 2001, p. 6.13). The only legitimate justification is a case specific approach, with authorisation and guidelines supplied by the United Nations Security Council (UNSC). Yet a moral imperative does not arise or disappear according to institutional statements, for example humanitarian intervention would still have been justified in Haiti without the OAS (Organisation of American States) sanctioning (Smith, 2009, p. 79), and the NATO intervention Kosovo without a Security Council mandate can be recognised as "illegal but legitimate", as "sanctioned by its compelling moral purpose" (Bellamy, 2009a, p. 106). The mandate that is important for a humanitarian intervention is founded in the 'Just War' tradition (Gordon, 1997, p. 108-112), a moral claim, that under certain conditions, legal restrictions become void, Quod est necessarium est licitum - 'that which is necessary is legal'. In short, and well encapsulated by José RamosHorta, the first Foreign Minister of an Independent East Timor, "Sometimes, a war saves people" (Ramos-Horta, 2005).

\section{Sovereignty}

"The debate about the legitimacy of humanitarian intervention hinges on the relative value afforded to sovereignty" (Bellamy, 2006a, p. 199). Widely regarded as the most important and identifying event in the history of international relations, the Treaty (or Peace) of Westphalia (1648) that ended the Thirty Years War, is enduringly significant for it guarantee's equality within the international order. That is, power, place and importance are removed as points of moral differentiation between states (Tutuianu, 2013, p. 44). Westphalian sovereignty has an equivalent in the norm of non-intervention (Garwood-Gowers, 2013, p. 84), as explained by Tony Blair in 2004, "a country's internal affairs are for it and you don't interfere unless it threatens you" (Byers, 2005, p. 107). This normative claim was formed with the explicit raison d'etre of securing international peace and the lives of all global citizens, empowering nationstates at the prejudice of international conflict and empire. Especially prescient in the era of decolonisation, and reinvigorated by the collapse of the world's last empire in the Soviet Union (Adelman, 2002, p. 3), the claim to sovereignty and non-intervention in the affairs of other nations was held onto with a religious vigour. A long history of colonisation and imperialist pursuits in international relations has made the promise of self-determination and a future free from outside interference, a deeply emotional attachment (Thakur, 2006, p. 266). Explained by Gareth Evans, "Sovereignty thus hard won, and proudly enjoyed, is sovereignty not easily relinquished or compromised” (Evans, 2006, p. xiv).

Sovereignty is the key founding tenet of international peace and cooperation, revered as highly as to be "the one and only organising principle in respect of the dry surface of the globe" (Schrijver, 2000, p. 69-70). By protecting for "the independent and unfettered power of a state in its jurisdiction" (Weiss, 2007, p. 12), sovereignty also demarcates "the stopping place of authority. This is why it is such an important political concept" (Gordon, 1997, p. 13). Algerian President, and then President of the Organisation of African Unity (OAU), 
Abdelaziz Bouteflika, in addressing the UN General Assembly in 1999, advocated the value of sovereignty as "our final defence against the rules of an unjust world" (Weiss, 2007, p. 16). As such, humanitarian interventions, such as that in Kosovo, brought vehement criticism from prominent international figures. Former Secretary of State and realist scholar, Henry Kissinger lambasted British Prime Minister Tony Blair after the intervention in Kosovo for the "abrupt abandonment of the concept of national sovereignty" (Bass, 2008,p. 12). Nelsen Mandela in 2000, saw military action in Kosovo as: "such disregard for international conventions was more dangerous to world peace than anything that was currently happening in Africa" (Chomsky, 2012, p. 5). Similarly, military historian Ze'ev Schiff lamented the destruction of the international order: "Israel will do to Lebanon what NATO did to Kosovo" (Chomsky, 2012, p. 5). In 1999, Sam Huntington cautioned that the US was becoming perceived by the international community as the "single greatest external threat to their societies... [a] rogue superpower" (Huntington, 1999). Intervention is morally reprehensible for it weakens the entire international order (Weiss, 2007, p. 15), highlighted by Secretary of State to President James Monroe, John Quincy Adams, asserting that the United States "does not go abroad, in search of monsters to destroy", it was a nation that "respected the independence of other nations while asserting and maintaining her own" (Bass, 2008,p. 89). Henry Kissinger explains the importance of the principle of sovereignty with a sharp history lesson, "Those who sneer at history obviously do not recall that the legal doctrine of national sovereignty and the principle of non-interference - enshrined, by the way, in the UN Charter - emerged at the end of devastating Thirty Years War, to inhibit a repetition of the depredations of the $17^{\text {th }}$ century, during which perhaps 40 percent of the population of central Europe perished in the name of competing versions of universal truth" (Bass, 2008, p. 12).

Equal sovereignty is the cornerstone of international law (ICISS, 2001,p. 1.32), "the basic constitutional doctrine of the law of nations" (Schrijver, 2000, p. 69-70). Legal sovereignty is directly relational to a distinctive territory, and the right within such territory of 'prescriptive jurisdiction' and 'enforcement jurisdiction'. Modern institutional architecture originates with the Montevideo Convention on the Rights and Duties of States 1933, indicating the four conditions for statehood and as such sovereign recognition, "a permanent population, a defined territory, a functioning government, and the ability to enter into relations with other states" (Weiss, 2007, p. 14). With similar references found in all significant regional constitutional documents (Gordon, 1997, p. 94), "independent sovereign statehood" became a cornerstone element of UN membership (1945) (ICISS, 2001, p. 2.11). Article 2(7) of the UN Charter exemplifies the normative standard of non-intervention (ICISS, 2001, p. 2.8), Article 2(4) condemns "the threat or use of force against the territorial integrity or political independence of any state" (Thakur, 2006, p. 246), whilst Article 2(1) highlights the "sovereign equality of all its members" as fundamental to the world order (Weiss, 2007, p. 15). Article 15, of the Charter of the Organisation of American States (1948), declares "no state or group of states has the right to intervene directly or indirectly, for any reason whatever, in the internal or external affairs of any other state". An unequivocal statement of the right to 
non-intervention, for which similar sentiments are found in the Charter for the Organisation of African Unity (later the African Union), and the constitutional arrangements of regional organisations in the Middle East and Asia (Gordon, 1997, p. 94). The International Court of Justice (ICJ) (1949) officially recognised that "between independent states, respect for territorial sovereignty is an essential foundation of international relations", then reaffirmed as such in 1986 when observing "the fundamental principle of state sovereignty on which the whole of international law rests" (Weiss, 2007, p. 15). The Declaration on World Peace and Cooperation, from the Bandung Conference (1955), Highlighted the importance of sovereignty, particularly for weaker nations or those with a history of colonial occupation (Hehir, 2004, p. 26). The Declaration on Principles of International Law concerning Friendly Relations and Cooperation among States (1970) emphasised that the UN was "convinced that the strict observance by states of the obligation not to intervene in the affairs of any other is an essential condition to ensure that nations live together in peace". The ICJ in the case of Nicaragua $v$ the United States (1986), adamantly asserted that self-defence, as understood in the UN Charter, must be applied "restrictively" (Hehir, 2008, p. 16). The Restatement of Foreign Relations Law (US) (1987) "Whether a state may intervene with military force in the territory of another state without its consent... to prevent or terminate human rights violations, is not agreed or authoritatively determined" (Hehir, 2008, p. 18). And at the 2000 South Summit of the G77 (now expanded to 133 countries) - an organisation comprising 80 per cent of the global population - the official declaration read: "we reject the so-called 'right' of humanitarian intervention" (Chomsky, 2012, p. 4).

Beyond legal structures and an institutional importance,"Sovereignty incarnates a moral value - which is extremely precious to us - which is the sovereign equality of peoples, the sovereign equality of states, and the protection that the sovereign system provides weak states against the might of the strong" (Ignatieff, 2011). In a vastly unequal international environment, sovereignty is the best, and in some cases, only defensive mechanism when confronted by states with dramatically greater resources, wealth, military strength and influence (ICISS, 2001, p. 1.32). The idea of statehood is an idea of "collectivity", and every state is an equal "member of the club" (Adelman, 2002, p. 4). For states, sovereignty is "recognition of their equal worth and dignity, a protection of their unique identities and their national freedom, and an affirmation of their right to shape and determine their own destiny" (ICISS, 2001, p. 1.32). As such, "Intervention violates a state's rights because it is violating the right of a people to live undisturbed by foreigners in a political community of their own" (Heinze, 2009, p. 20).

\section{The Dilemma \& The 1990's}

The individual is protected by humanitarian intervention, while the state is protected by territorial sovereignty and the norm of non-intervention. This was a problem of theory that exploded into practice in the early 1990's as "a time of heightened expectations for 
effective collective action following the end of the Cold War" (ICISS, 2001, p. 1). With the shadow of great power conflict falling away over the globe, a greater level of attention and nuance was suddenly applied to more parochial conflicts; issues of humanitarianism and obligations of the international community as a collective moral and institutional force. As such, the contrasting moral and legal principles of a state's right to non-interference and the individual's right to protection under humanitarian intervention were drawn to the fore (Barnett, 2011, p. 6).

To compound this renewed focus, this was also a period of history where non-combatants became the primary victims of conflict and unrest more than ever before (Holt \& Berkman, 2006, p. 16). The long term outcome of which could be felt in the displacement of a full one percent of the global population, with another one percent forced into situations of intense desolation and a lack of basic dignity (Weiss, 2005, p. xxvii). To address this, interventions, or the lack thereof, in conflict zones such as Somalia, Yugoslavia, Rwanda, Iraq, Kosovo, East-Timor, Haiti, Liberia, Democratic Republic of Congo (DRC), Uganda, and Sierra Leone, amongst others, represented empirical examples of the conflicted thinking behind humanitarian intervention and state sovereignty. In short, "the international community's actual record of preventing and halting the mass killing of civilians is staggeringly poor" (Bellamy, 2011, p. 1). The selective and disjointed application of humanitarian intervention, indicated that uncertainty had become the normative standard in the application of humanitarian intervention. State behaviour was not governed by a consistent set of rules when confronted by mass atrocities; the theoretical void between the principle of non-intervention and the moral imperative of protecting at-risk segments of humanity was engulfing the majority of global conflicts (Thakur, 2006, p. 246). The solution to this was going to be the Doctrine of the Responsibility to Protect (R2P).

\section{The Responsibility to Protect (R2P)}

The Doctrine of the Responsibility to Protect (R2P) is an expression of international "dismay" at the human atrocities of the 1990's (Garwood-Gowers, 2013, p. 82), and "the ineffective international responses to halting them" (Evans, 2012). R2P was created with the purpose of being a mechanism to "bridge the sovereignty versus intervention divide" (Evans, 2006, p. 712), a way of "reconciling the principle of shared responsibility with that of non-intervention" (ICISS, 2001, p. 8.3). By signing the United Nations Charter and other international obligations, the majority of states had previously accepted limits on their sovereignty, however R2P stepped beyond this to outline a further obligation upon the international community as a whole, in relation to third party occurrences of mass atrocities. This obligation had legal precedent in the ICJ report concerning Bosnia vs. Serbia, Common Article 1 of the Geneva Conventions (1949), the Draft Articles on the Responsibility of States for Internationally Wrongful Acts, by the International Law Commission and the UN's independent inquiry following the genocide in Rwanda (Bellamy, 2010, p. 161). 
The Doctrine of the Responsibility to Protect was originally proposed by the International Commission on Intervention and State Sovereignty (ICISS) report (2001), whereby state sovereignty, as a principle, became refined, and narrowed into 'functional sovereignty', thereby moving beyond previous normative sovereign limitations. This re-imagining was based upon the three pillars of: (1) Sovereignty being conditional upon the protection of civilian populations, (2) By requiring the international community to assist in this regard, and (3) By 'obligating' international humanitarian intervention whenever this standard cannot be met in regard to the manifestation of ethnic cleansing, genocide, crimes against humanity, and grave or systemic war crimes, (the Four Crimes) (Bellamy, 2010, p. 143).

R2P obligations were categorised into the Responsibility to Prevent (R2Prevent), the Responsibility to React (R2React) and the Responsibility to Rebuild (R2Rebuild), and were limited to the 'Just War Theory' conditions of 'right intention', 'last resort', 'proportional means', 'reasonable prospects' 'right authority' and 'just cause' (ICISS, 2001). To reconceptualise sovereignty as such is practically significant in three distinct ways, firstly it outlines the responsibility of states for the protection and promotion of its citizens lives. Secondly, it means states have a dual responsibility to their citizens and also to the international community; internal and external responsibilities. And lastly, it entails that actions of a state and those undertaken by agents on behalf of the state, will be held to account for their actions (ICISS, 2001, p. 2.15).

R2P moved from concept, to legal principle (Hehir, 2012,p. 19) and normative consensus (Weiss, 2007, p. 1) when it was adopted at the UN World Summit in 2005. Six months later it was reaffirmed; again in 2009 at the United Nations General Assembly (UNGA) debate on "implementing the Responsibility to Protect" (2009), and again in 2011. R2P rapidly became an "obligatory reference point in academic discourse on the issue of humanitarian intervention" (Hehir, 2012, p. 4). R2P has been referenced in United Nations Security Council (UNSC) Presidential statements concerning the protection of civilians in armed conflict, international peace and security, children in armed conflict and the Middle-East, peace and security in Africa, and Central Africa, whilst also playing a significant role in various aspects of institutional architecture, including the Peacebuilding Commission. Moreover, R2P was explicitly cited in declarations concerning the protection of civilians in armed conflict, children in armed conflict, and the control of small and light weapons, as well as UNSC resolutions relating to Sudan, Democratic Republic of Congo (DRC), Cote d'Ivoire, Mali, Yemen, Central African Republic, Burundi and Libya (Evans, 2006, p. 714; Bellamy, 2011, p. 110).

Kenya was largely seen as a successful example of R2P in practice (Bellamy, 2010, p. 154). As with Sri Lanka (Bellamy, 2011: 88), the use of R2P language "is widely credited with having helped... stave off the escalation of violence in Kenya" (Bellamy, 2010, p. 153). Following the Presidential election in Kenya in 2007, and the outbreak of violence resulting in 1000 deaths and 250,000 displaced people, Francis Deng, through the authority of the Special Advisor on the Prevention of Genocide (OSAPG), employed the rhetoric of R2P as 
directly relating to the charge of the incitement of violence by political leaders. As a result the live broadcasting of inflammatory speeches and comment was banned, undoubtedly saving significant amounts of human suffering (Hehir, 2012, p. 131).

Libya stands as the keystone of R2P. Originally, following Muammar Gaddafi's initial crackdown, then also on February 26 in relation to arms embargoes, travel restrictions, asset freezes, and an ICC referral, and finally on March 17 with resolution 1973 authorising military intervention to protect Libyan rebels and citizens from being targeted by Gaddafi and his regime, R2P was the driving force behind international condemnation and intervention in Libya in 2011 (Garwood-Gowers, 2013, p. 87-88). Faced with rebels, primarily focussed on democratic reform, Colonel Gaddafi made his intentions explicit, "We are coming tonight... we will find you in your closets... we will show no mercy" (Hehir, 2012, p. 13). Resolution 1973 was seen as the embodiment of humanitarian principles, and with a successful international mobilisation and successful application, with Gaddafi dead and the regime removed from power by October that year (Hehir, 2012, p. 12), Libya was seen as a watermark for R2P, as a position from which "we can say no more Holocausts, Cambodias, and Rwandas" (Weiss, 2011, p. 5).

Put simply, when military intervention was undertaken, or being discussed, R2P was prominent (Weiss, 2005, p. 192, Orford 2010:336). Within this new atmosphere and hope created by R2P, Gareth Evan said "Maybe, just maybe, we'll be able to say 'never again' in the future without having to periodically look back, as has so often been the case in the past, asking ourselves, with a mixture of anger, incomprehension and shame, how did it happen again" (Stark, 2011); Jack Straw, as British Foreign Minister, believed "if this new responsibility had been in place a decade ago, thousands in Srebrenica and Rwanda would have been saved" (Hehir, 2012, p. 127); and Kofi Annan exclaimed "I believe we must embrace the responsibility to protect, and, when necessary, we must act on it" (Evans, 2006, p. 714). The force behind humanitarian intervention reached new heights with R2P, as explained by the ICISS report itself: "This report has been about compelling human need, about populations at risk of slaughter, ethnic cleansing and starvation. It has been about the responsibility of sovereign states to protect their own people from such harm - and about the need for the larger international community to exercise that responsibility if states are unwilling or unable to do so themselves" (ICISS, 2001, p. 8.1).

\section{The Failure of R2P}

R2P produced a broad international consensus, at least in principle, and certainly altered some of the justifying language that surrounded any potential, or actual, humanitarian intervention, but in practice R2P always existed as an indeterminate principle. Gareth Evans, commenting on this failure of the doctrine to move from theory into action, accused the international community of having "buyer's remorse" (Bellamy, 2010). In "terminal decline" due to its "inherent malleability" R2P was suffering from the same reluctance and 
haphazard application that humanitarian intervention before it suffered from (Hehir, 2008, p. 74-75).

The international intervention in Libya was held up as a keystone moment for R2P, however it was authorised in the same manner that it would have been pre-R2P, that is, under Chapter VII of the UN Charter (Hehir, 2012,p. 13). Beyond this, Resolution 1973 was seen to be deliberately avoiding making explicit reference to R2P through the ambiguous wording of, "reiterating the responsibility of the Libyan authorities to protect the Libyan population" (Hehir, 2012, p. 13), and avoided any mention of the international community's responsibility to protect the Libyan population. In the UNSC, the important international actors of Russia, China, India and Brazil chose to abstain rather than endorse Resolution 1973 (Garwood-Gowers, 2013, p. 82), while the BRICS (Brazil, Russia, India, China and South Africa) nations expressed strong misgivings regarding the invocation and application of R2P (Garwood-Gowers, 2013, p. 88). Beyond this, neither in the co-authored justification by Nicolas Sarkozy, David Cameron and Barak Obama, nor in Obama's own keynote speech supporting and explaining the Libyan intervention, nor within Resolution 1973 itself, was a reference to R2P explicitly made (Hehir, 2012, p. 13-15). "There is nothing in Resolution 1973 which can reasonably be deemed evidence that R2P has catalysed a permanent change in the disposition of the P5" (Hehir, 2012, p. 19), and the perceived mission creep/ mandate abuse that occurred by NATO forces has seemingly damaged R2P and humanitarian intervention into the future, with the UNSC constantly found deadlocked on resolutions concerning intervention in Syria beyond observer missions and resolution 2188 pertaining to the destruction of chemical weapons under the 'Chemical Weapons Convention', not the protection of civilians under R2P (Garwood-Gowers, 2013, p. 82, 94).

Five years after the onset of the violence in Darfur, 290,000 people had been displaced in the first 10 months of 2008 alone, and four million were in need of urgent humanitarian assistance (Hehir, 2012, p. 133; Coalition of NGO's on Darfur, 2008, p. 7-8), motivating the British Parliament to issue the statement "if the responsibility to protect means anything, it ought to mean something in Darfur" (Bellamy, 2011, p. 52-54). And in a UNSC resolution condemning Khartoum, and also in authorising an UN-led peacekeeping mission, R2P was explicitly declared (Hehir, 2012, p. 133). However, UN efforts to adsorb AU forces and take control of operations were halted when it became apparent that the key players in the international community were simply unwilling to supply the necessary troops $(12,000$ to 20,000) (Weiss, 2007, p. 55), and deliberations on Darfur in the UN Human Rights Council (2007) were effectively shut down as members protested against the applicability of R2P (Bellamy, 2011, p. 29). Moreover, whereas R2P explicitly does not require consent from targeted states, UNSC resolution 1706 invited "the consent of the Government of National Unity" (Hehir, 2004, p. 67), with the subsequent lack of permission from the Sudanese government forming an unmanageable hurdle for the international community (Schulz, 2009, p. 150). As such, R2P, contrary to its framed intentions, actually helped to facilitate international obfuscation, by affording member states the ability to claim that "in the spirit 
of 'the responsibility to protect', host states have the primary responsibility to deal with intra-state crises and should be left alone to do so" (Hehir, 2004, p. 93, 125). Articulated by Lee Feinstein, "If Darfur is the first 'test case' of the responsibility to protect there is no point in denying that the world has failed the entry exam" (Feinstein, 2006, p. 38). It did more than that, Darfur became the "Ground Zero" of the doctrine (Schulz, 2009, p. 150).

Kenya was held up as "a successful example of R2P at work" by Kofi Annan, yet it is doubtful as to what impact R2P actually had. R2P was loosely employed during the crisis, and used more as a "diplomatic tool than catalyst for action" (Bellamy, 2011,p. 89). Moreover, the use of the doctrine at all, draws serious questions about its content and the threshold for its use. With zero evidence of ethnic cleansing, and only 700-800 confirmed deaths, Kenya ought never to have drawn the attention of R2P, by its own stated directives (Bellamy, 2011, p. 54-55).

The plight of civilians caught in the middle of a Sri Lankan government offensive against the Liberation Tigers of Tamil Eelam (LTTE), prompted widespread calls for the UNSC to invoke R2P. Bringing India to publicly remind the Sri Lankan government that it holds "a responsibility to protect its own citizens", yet despite public opinion having no effect on the Sri Lankan government, the UNSC failed to deliver an R2P resolution, leaving the 150,000 at risk civilians unprotected (Bellamy, 2011,p.60-62). Noted by Human Rights Watch,"there was a failure to address the Sri Lankan issue and that I think can be said to be indicative of where the gap between the words and the reality is" (Crawshaw, 2009).

In Mali, despite three separate UN resolutions authorising action, and the expressed support of ECOWAS to assist the government in combating Islamic militants, it required unilateral intervention by France (Operation Serval) to precipitate broader international assistance. In Somalia, an international reluctance to use the language of R2P formed in relation to the presence of humanitarian emergencies, as a means of avoiding the residual obligations (Bellamy, 2011, p. 89). And a UN Commission of Inquiry reported that the government in Guinea had committed crimes against humanity in its repression of opposition protests, yet R2P was nowhere to be seen.

Despite a broad consensus that $\mathrm{R} 2 \mathrm{P}$ is applicable for the ongoing situation in the Democratic Republic of Congo (DRC), the UNSC has as yet failed to authorise intervention under the guise of R2P, with a debate persisting as to whether viewing the situations in DRC through the 'prism of R2P' is helpful to achieve results on the ground. Moreover, it is important to note that troop expansions, mandate strengthening, and greater assistance, though delivered after the implementation of R2P, was all guaranteed prior to 2005 (Bellamy, 2011, p. 51-52); the implementation of R2P has had no perceptible impact on the DRC (Bellamy, 2011, p. 89).

Israel's assault on the Gaza strip was raised at the UNGA in 2009, where it was argued that as a population under occupation, the citizens of Gaza, now being targeted by the occupying state, were manifestly in need of an R2P resolution. The failure of such an eventuation, led to calls of "selective application" and "double standards" (Bellamy, 2011, p. 58-60). As has the failure of the UNSC to pass an R2P resolution authorising a protection mandate 
for oppressed citizens in Zimbabwe (Garwood-Gowers, 2013, p. 85-86), and the failure of North Korea to attract the attention of R2P in any form, despite the existence of a 2008 report that detailed how the country was a "serial offender", charging that it had inflicted a "regime-induced famine", and "failed in its responsibility to protect its own citizens from the most severe violations of international law"(Bellamy, 2011, p. 67-68).

Yet still more damaging moments for R2P came about by virtue of its misappropriation. France used the doctrine to try to force an intervention upon Myanmar following cyclone Nargis, with the stated goal of distributing aid; thereby ignoring the need for the presence of the four crimes (Bellamy, 2010, p. 151-152). Russia employed the language of R2P as a "Trojan Horse" to annex South Ossetia, with Russian Foreign Minister, Sergei Lavrov claiming that the proximity of the conflict "makes it absolutely unavoidable to us to exercise responsibility to protect" (Bellamy, 2011, p. 55-56). And Tony Blair used R2P in order to try and justify, in retrospect, the 2003 invasion of Iraq (Weiss, 2007, p. 124), claiming "[w]e surely have a responsibility to act when a nation's people are subjected to a regime such as Saddam's" (Byers, 2005, p. 107). This despite not matching with the stated aims at the time of intervention, nor with any conceivable 'present' manifestation of the four crimes (Evans, 2006, p. 717).

Empirical failures aside, institutionally, R2P fell short of what it was hoped to be. From the outset, there was confusion amongst member states as to what R2P actually was. Some states believed that they were agreeing implicitly upon the ICISS report (Chomsky, 2012, p. 60), not just the World Summit agreement, whilst others believed that despite signing up, that they in fact had not agreed to R2P in any capacity (Evans, 2009, p. 52). R2P was nothing more than a "political catchword that gained quick acceptance because it could be interpreted by different actors in different ways" (Stahn, 2007, p. 99-102). Beyond this, the World Summit outcome was in itself already an explicit "watering down" of the original ICISS report (Weiss, 2007, p. 57). In this process, the ICISS threshold for intervention, namely "large scale loss of life", was replaced by the higher barrier of the 'four crimes', whilst the failing standard of state protection was lowered from the ICISS "unwilling or unable" to protect, to the new standard of "manifestly failing" to protect (Garwood-Gowers, 2013, p. 84). Furthermore, the World Summit outcome highlights the key role of host-nation responsibility, which implicitly reduces the responsibility placed on the international community from 'equal' to 'secondary', and the binding term "obligation" was removed altogether (Holt \& Berkman, 2006, p. 32; Weiss, 2007, p. 57; Hehir, 2012, p. 19). But perhaps most crippling of all, the 'code of conduct' of the Permanent Five (P5) members of the UNSC was eliminated (Hehir, 2008, p. 71), alternatives to UNSC authorisation were removed (ICISS, 2001, p. 3.31 \& 3.35) and the absolutist role of the UNSC with discretion over interventions was reaffirmed (Hehir, 2012, p. 19). By the end, even if agreement on its meaning could have been achieved, the World Summit outcome did nothing more than re-state what were already accepted principles of international relations (Chomsky, 2012, p. 160-161; Hehir, 2012, p. 52). 


\section{Political Will}

The barrier that R2P believed it was overcoming, namely that of state sovereignty, be it conceptually, legally, or normatively, simply never existed with the inviolability that it was imagined to have (Weiss, 2007, p. 12,16). Sovereignty was only ever absolute and sacrosanct as an emotional claim, rather it has always been limited in all practical matters (Schrijver, 2000, p. 69-70), and its violation has been commonplace (Weiss, 2007, p. 13). Sovereignty, as recognised in the UN Charter, exists only under the provision that international peace and security are maintained (Weiss, 2007, p. 16). Article 1(3) of the UN Charter requires states to "achieve international co-operation in solving international problems of an economic, social, cultural, or humanitarian character, and in promoting and encouraging respect for human rights" (Weiss, 2007, p. 17) The ICJ has ruled that Chapter 1, Article 2 (7), when asserting that "nothing contained in the present Charter shall authorize the United Nations to intervene in matters which are essentially within the domestic jurisdiction of any state", could only be understood within the context of development within international relations, that is, the term "domestic jurisdiction" is not a "fixed content" (Weiss, 2007, p. 17). Beyond this, sovereignty has been limited in practice by treaties and customary law, with states refusing the use of sovereignty as an overriding legal principle in order to strengthen international legal responsibility agreed between states (Weiss, 2007, p. 17).

During the 1990's, acts such as the UN resolution authorising the no-fly zone over Iraqi-Kurdistan, were seen as the embodiment of a 'right to intervene' and the death of "the age of strict national sovereignty" (Ignatieff, 1999, p. 91). The capacity to intervene in crisis zones such as Rwanda and Darfur, was conceivably legitimised, as designated by the Genocide Convention (Hehir, 2012,p. 128-129). The formation of the International Criminal Tribunals on Rwanda and Yugoslavia, and the creation of the International Criminal Court (ICC) represented an acknowledgment of universal jurisdiction, an evidential shift in the understanding of international law (Weiss, 2007, p. 48). Since 1945, International law, human rights and the evolving realm of human security have substantially reconstructed sovereignty in practice (ICISS, 2001, p. 1.33), with ICISS itself conceding that it "heard no such claim [of absolute sovereignty] at any stage during our worldwide consultations" (ICISS, 2001, p. 1.35). Then UN Secretary General Boutros Boutros-Ghali declared "the time of absolute state sovereignty... has passed" (Weiss, 2007, p. 18), Kofi Annan explained the right of intervention in 1999, as “it is the people's sovereignty rather than the sovereign's sovereignty" (Weiss, 2007, p. 22), and Francis Deng and Roberta Cohen were articulating "sovereignty as responsibility" as early as the 1980's in regards to international obligations toward internally displaced people (Weiss, 2007, p. 22 \& 92).

So R2P, though be it inadvertently, offered a clarification over the values once attached to perceived competing ideals of state sovereignty and humanitarian intervention. The disjunctive application and outright failures of the 1990's and early 2000's indicated for most people the presence of a 'sovereign dilemma'; R2P ought to have solved this issue. 
Rather what was missing all along, and the fundamental problem holding humanitarian intervention, and later R2P, back was the sheer absence of motivation and ethical will (Weiss, 2007, p. 51). The barrier that sovereignty was imagined to be against humanitarian best practice, was in fact something much more elemental. Explained by Alex Bellamy, the reason that humanitarian intervention was failing pre-R2P (and subsequently post-R2P), was "the basic political fact that no state wanted to pay the price associated with saving strangers" (Bellamy, 2011, p. 4).

Sovereignty, as a barrier to humanitarian intervention, was nothing more than a parochial misconception; the point at issue was always the opposing concerns of "ethics versus politics" (Barnett, 2011,p. 6). Regardless of the legal frameworks, institutional structures, or authorisation, humanitarian intervention was always "limited to situations in which states had the political will to bear substantial financial and human costs" (Weiss, 2007, p. 51).

Following the World Summit Outcome, Lee Feinstein observed that as important as R2P was, it was also entirely predicated on "the political will to back it up" (Feinstein, 2007). Aidan Hehir explained that "political will is the variable upon which the entire utility of R2P is now predicated" (Hehir, 2012, p. 53). The Swiss representation at the General Assembly Debate in 2009, recognised the need of "political will at the right time", the Canadian delegation openly declared that R2P was contingent upon "the goodwill of states", and the United States implored the international community to "work to summon the courage of our convictions - and the will to act" (Hehir, 2012, p. 127). In his capacity as co-chair of the ICISS report, Gareth Evans, recognised that "without the exercise of political will, by the relevant policy makers at the relevant time, almost none of the things for which this book has argued will actually happen" (Evans, 2008, p. 119). Investigating the success and failure of UN operations, the Secretary-General commissioned 'Report of the High-Level Panel' emphasized the failures of the UNSC in terms of the "willingness to act in defence of the common peace" (Thakur, 2006, p. 302). Humanitarian intervention has always hinged upon "the disposition of statesmen" (Hehir, 2012, p. 119) and the issue of 'political will' (Bellamy, 2009, p. 119). Accordingly, the failure of R2P was reducible to its failure to produce any increased degree of "compliance pull" when compared to what existed previously (Bellamy, 2010, p. 159).

The failure to secure a reasonable intervention during the Rwandan genocide was, according to Ramesh Thakur, due to a failure of "civic courage" and "collective conscience" (Thakur, 2006, p. 245), an UN post-mortem inquiry pointed to a "lack of resources and political commitment" (Bellamy, 2011, p. 4), and the ICISS report described it as "a failure of international will" (ICISS, 2001, p. 1). A reasonable assertion considering that Force Commander of the UN Assistance Mission in Rwanda (UNAMIR), Canadian Major-General Romeo Dallaire, has maintained the view that he could have stop the genocide, saving hundreds of thousands of lives, if the UN had supplied him with as little as 5000 adequately trained, equipped and mandated troops (Thakur, 2006, p. 293). In regards to the Kosovo intervention, the ICISS report acknowledged that a humanitarian guise was created by NATO 
in order to "manipulate external intervention to advance their political purposes" (ICISS, 2001, p. 1), acknowledged by Tony Blair at the time, by claiming that such interventions were important for "we have national interests involved" (Hehir, 2012, p. 137-138). Highlighting this, by mid-1999 the UNHCR dealing with the primary humanitarian concern resulting from the intervention, had only received 25 percent of the funds required (Weiss \& Collins, 2000, p. 100).

In East Timor, a senior diplomat in Jakarta described the international community's reluctance to intervene (other than Australia) as "Indonesia matters and East Timor doesn't" (Chomsky, 2012, p. 76-77). According to Aidan Hehir, "it was clear that no intervention would take place without Indonesia's consent" (Hehir, 2004, p. 55). And, Thomas Weiss describes the "feeble" international response to the ethnic cleansing in Bosnia, that "lent a disgraceful connotation to 'peacekeeping"', as a "collective spinelessness" (Weiss, 2005, p. 77-81). To support this, the UN Report into the Srebrenica massacre, and the feeble international commitment, as a crisis of political will: "The cardinal lesson of Srebrenica is that a deliberate and systematic attempt to terrorize, expel or murder an entire people must be met decisively... with the [requisite] political will" (Report of the Secretary-General, 1999, para $499 \& 502$ ).

In the DRC, where it has been considered that the conflict would have been reasonably easy to halt (Weiss, 2009, p. 127), the sheer lack of any political will to support the rhetoric of the international community, produced a situation where the proposed "humanitarian intervention melted into air" (Adelman, 2002, p. 17). And when it became obvious that the international community had no intention of acting in Darfur, operating in a manner described as "hesitant, timid and equivocal" (Hehir, 2004, p. 68), Kofi Annan commented "we had learnt nothing from Rwanda" (Hehir, 2012, p. 120). Alex Bellamy considered that "in relation to Darfur... [R2P] is typically rated an abject failure in that it failed to galvanise international action" (Bellamy, 2010, p. 153).

The ICISS report saw the collapse of the intervention in Somalia as "flawed planning" and "poor execution" emanating from an absence of political will (ICISS, 2001, p. 1). Commenting on the humanitarian crisis in Sri Lanka (2008-2009), Steve Crawshaw from Human Rights Watch, claimed "there was a failure to address the Sri Lankan issue and that I think can be said to be indicative of where the gap between the words and the reality is" (Crawshaw, 2009). While, a 2008 report concluded that North Korea had "failed in its responsibility to protect its own citizens from the most severe violations of international law" via a "regimeinduced famine", and huge numbers of arbitrary executions and systematic torture. Since the implementation of R2P in 2005, North Korea has proven to be "one of the world's worst mass murderers", and in regards of crimes against humanity, a "serial offender". Yet, North Korea has failed to attract the attention of the R2P prism, "almost entirely overlooked" as an applicable situation (Bellamy, 2011, p. 67-68)

Public intellectual and author, Bernard-Henri Levy, after working closely with the French government concerning the Libyan intervention, explained that the intervention succeeded 
- whereas others have failed to get off the ground - due to the single issue of "the political will of one man, the President of the French Republic, Nicolas Sarkozy" (Hehir, 2012, p. 16-17). Thereby also offering the query of: 'if Libya, then why not Bahrain, Yemen, or Syria?' Concerning the ever deepening humanitarian crisis and degrading terrorist state in Syria, and the American administration's failure to intervene, Defence Secretary, Leon Panetta, looking back on the situation said: "We learned a lot about how to confront al-Qaeda and its affiliates as a result of operations in Pakistan and Afghanistan"..."We know how to do this. But we have to be willing to do it" (Warrick, 2015, p. Ch 20).

\section{Conclusions}

The Responsibility to Protect was conceived in order to be a bridge over the barrier that many people had assumed state sovereignty placed to humanitarianism. Yet this was a misconception over what sovereignty was prior to R2P, and a misunderstanding over why states were only undertaking humanitarian interventions in an indeterminate, largely unsupportive manner. States once willing and capable of undertaking significant imperial and colonial excursions, are simply avoiding similar burdens for a different principle - humanitarianism (Ignatieff, 1999, p. 107). The failures of humanitarian intervention, just as with R2P afterwards, can be understood via the simple statement that: "states choose not to undertake them" (Chesterman, 2003, p. 54). So, in the words of Mohammed Sahnoun and Gareth Evans, as Co-chairs of the ICISS Report: "It is only a matter of time before reports emerge again from somewhere of massacres, mass starvation, rape, and ethnic cleansing" (Evans \& Sahnoun, 2002, p. 100).

\section{References}

Adelman, H. (2002). “Theory and Humanitarian Intervention”. In Keren, M. \& Sylvan, D.A. (eds). International Intervention: Sovereignty versus Responsibility. Cornwall: Frank Cass Publishing.

Barnett, M. (2011). Empire of Humanity: A History of Humanitarian Intervention. USA: Cornell University Press.

Bass, G.J. (2008). Freedom's Battle: The Origins of Humanitarian Intervention. New York: Alfred, A. Knopf Publishing.

Bellamy, A. (2006)."Whither the Responsibility to Protect? Humanitarian Intervention and the 2005 World Summit". Ethics and International Affairs 20(2).

Bellamy A.J. (2006a). Just Wars: From Cicero to Iraq. Cambridge: Polity Press.

Bellamy, A. (2009). Responsibility to Protect: The Global Effort to End Mass Atrocities. London; Polity.

Bellamy, A.J. (2009a)." "Responsibility to Protect or Trojan Horse?" In Barry, C. \& Rosenthal, J.H. (eds). Ethics \& International Affairs: A Reader Georgetown: Georgetown University Press.

Bellamy, A. J. (2010). “The Responsibility to Protect - Five Years On". Ethics \& International Affairs 24(2), p. $143-169$ 
Bellamy, A.J. (2011). Global Politics and the Responsibility to Protect: From Words to Deeds. New York: Routledge.

Byers, M. (2005). War Law: Understanding International Law and Armed Conflict. USA: Grove Press.

Coalition of NGO's on Darfur (2008). Rhetoric vs. Reality: The Situation in Darfur.

Chesterman, S. (2003). Hard Cases Make Bad Law. In Lang, A. (ed). Just Intervention. Washington, D.C.: Georgetown University Press.

Chomsky, N. (2012). A New Generation Draws the Line: Humanitarian Intervention and the 'Responsibility to Protect' Today. USA: Paradigm Publishers.

Crawshaw, S. (2009). "Interview between Aidan Hehir and Steve Crawshaw". Human Rights Watch, (17 August: New York).

Evans, G. (2006). “From Humanitarian Intervention to the Responsibility to Protect” Wisconsin International Law Journal 24(3), p. 703-722.

Evans, G. (2012). “Forward” In Breakey, H. \& Francis, A. \& Popovski, V. \& Sampford, C. \& Smith, M.G. \& Thakur, M.G. (eds). Enhancing Protection Capacity: A Policy Guide to the Responsibility to Protect and the Protection of Civilians in Armed Conflicts. Australia: Institute for Ethics, Governance and Law.

Evans, G. \& Sahnoun, M. (2002). “The Responsibility to Protect”. Foreign Affairs 81(6), p. 99-110.

Feinstein, L. (2007). “Beyond Words: Building Will and Capacity to Prevent More Darfurs". Washington Post. January 26, 2007, 12:00 AM - http://www.washingtonpost.com/wp-dyn/content/article/2007/01/25/ AR2007012501250.html.

Garwood-Gowers, A. (2013). “The BRICS and the Responsibility to Protect in Libya and Syria”. In Maguire, R. \& Lewis, B. \& Sampfort, V. (eds). Shifting Global Powers and International Law: Challenges and Opportunities. Great Britain: Routledge.

Gordon, G. (1997). Ethics and International Relations. Oxford: Blackwell Publishers.

Hehir, A. (2008). Humanitarian Intervention After Kosovo: Iraq, Darfur and the Record of Global Civil Society. Great Britain: Palgrave Macmillan.

Hehir, A. (2012). The Responsibility to Protect: Rhetoric, Reality and the Future of Humanitarian Intervention. China: Palgrave Macmillan.

Heinze, E.A. (2009). Waging Humanitarian War: The Ethics, Law and Politics of Humanitarian Intervention. New York: Suny Press.

Holt, V.K. \& Berkman, T.C. (2006). The Impossible Mandate? Military Preparedness, the Responsibility to Protect and Modern Peace Operations. Washington, D.C.: The Henry L. Stimson Center.

Huntington, S.P. (1984). “Will More Countries Become Democratic?”. Political Science Quarterly 99(2), 193-218.

ICISS (Report of the International Commission on Intervention and State Sovereignty) (2001). The Responsibility to Protect. Canada: International Development Research Centre.

Ignatieff, M. (1999). The Warrior's Honor: Ethnic War and the Modern Conscience. Great Britain: Vintage Publishing.

Ignatieff, M. (2011). "Reimagining a Global Ethic". Speech to the Carnegie Council. 10 November 2011, http://www.carnegiecouncil.org/studio/multimedia/20111110/index.html.

Orford, A. (2010). “The Passions of Protection: Sovereign Authority and Humanitarian War". In Fassin, D. \& Pandolfi, M. (eds). Contemporary States of Emergency: The Politics of Military and Humanitarian Interventions. New York: Zone Books.

Ramos-Horta, J. (2005). “Sometimes, A War Saves People”. In Cushman, T. \& Marx, G. \& Williams, C. (eds). A Matter of Principle. California: University of California Press. 
Schrijver, N. (2000). “The Changing Nature of State Sovereignty”. The British Year Book of International Law 1999" Oxford: Clarendon Press.

Schulz, W. (2009). "Spread wide the Word". Cooper, R.H. \& Kohler, J.V. (eds). In Responsibility to Protect: The Global Moral Compact for the $21^{\text {st }}$ Century. New York: Palgrave Macmillan.

Smith, M.J. (2009). "Humanitarian Intervention: An Overview of the Ethical Issues". In Barry, C. \& Rosenthal, J.H. (eds). Ethics \& International Affairs: A Reader. Georgetown: Georgetown University Press.

Stahn, C. (2007). Responsibility to Protect: Political Rhetoric or Emerging Legal Norm? The American Journal of International Law 101(1), p. 99-120.

Stark, A. (2011) Introduction”. “The Responsibility to Protect: Challenges \& Opportunities in Light of the Libyan Intervention. E-International Relations. November 2011 - http://www.e-ir.info/wp-content/ uploads/R2P.pdf.

Thakur, R. (2006). The United Nations, Peace and Security: From Collective Security to the Responsibility to Protect. Cambridge: Cambridge University Press.

Tutuianu, S. (2013). Towards Global Justice: Sovereignty in an Interdependent World. The Hague: Asser Press. United Nations (1999). Report of the Secretary-General Pursuant to General Assembly Resolution 53/35: The Fall of Srebrenica. United Nations General Assembly A/54/549. 15 November 1999. New York: UN Secretariat.

Warrick, J. (2015). Black Flags: The Rise of ISIS. Toronto: Doubleday.

Weiss, H.F. (2009). “The Democratic Republic of the Congo”. In Cooper, R.H. \& Kohler, J.V. (eds). Responsibility to Protect: The Global Moral Compact for the 21 $1^{\text {st }}$ Century. New York: Palgrave Macmillan.

Weiss, T.G. (2005). Military-Civilian Interactions: Humanitarian Crisis and the Responsibility to Protect $2^{\text {nd }}$ ed. USA: Rowman \& Littlefield Publishers, Inc.

Weiss, T.G. (2007). Humanitarian Intervention: Ideas in Action. UK: Polity Press.

Weiss, T.G. \& Collins, C. (2000). Humanitarian Challenges \& Intervention, $2^{\text {nd }}$ ed. Colorado: Westview Press.

\section{Author}

\section{Lea-Henry, Jed}

Vignan University, Department of Humanities and Social Sciences

Contact details: Vignan's University, Guntur, Andhra Pradesh, 522213, India

email: jedlea_sh@vignanuniversity.org 